\title{
Music Creation Environment of Music Poetry
}

\author{
Yanshuang Hou \\ Research Institute of Li Bai in Sichuan \\ Mianyang, China 621000 \\ School of Music \\ University of Jinan \\ Jinan, China 250000 \\ School of Education \\ Tianjin University \\ Tianjin, China 300072
}

\author{
Xinglong Guo \\ Research Institute of Li Bai in Sichuan \\ Mianyang, China 621000
}

\begin{abstract}
Li Bai lived in the flourishing period of Tang Dynasty in China. The flourishing period of Tang Dynasty was the heyday of the development of Chinese literature and art, with poetry and music as its representatives. At that time, "taking in everything with all flowers blooming" was the guiding ideology in the cultural aspects, and poetry, music, dance and other art categories interacted with each other and integrated together. A large number of $\mathrm{Li}$ Bai's poems contain elements of music, of which the reason is due to the circumstances of the time. Therefore, this article analyzes the two major parts of the creation stage of $\mathrm{Li}$ Bai's poetry with musical elements and the musical creation environment of $\mathbf{L i}$ Bai's poems, and draws the conclusion that the influence of the environment is the main reason why $\mathrm{Li}$ Bai's poetry has musical characteristics.
\end{abstract}

Keywords-Li Bai's poetry; creative environment; musical characteristics

\section{INTRODUCTION}

Li Bai (701-762), with the style name Taibai and pseudonym Qinglianjushi, was born in Chengji, Longxi (today's southwestern of Jingning in Gansu). His ancestors lived in Suiye (today's Tokmok in northern Kyrghyzstan) in the last years of the Sui Dynasty. In childhood, he moved to Qinglian Village of Changzhou County in Mianzhou (today's Jiangyou in Sichuan) with his father, and left hometown at a young age. When he was 25 years old, he parted with his parents to go elsewhere out of Sichuan with a sword. He has the patriotic heart of "sighing for several times at midnight due to the worry about the country", the heroic spirit of "drinking much wine ... ... his poetry occupied that of the half of Tang Dynasty", and the artistic feelings of "songs can shock the wood in forest, and Laugh can be compared to Thunder". Li Bai's poems have distinctive musical features. The main reason of the obvious musical elements of Li Bai's poems is inseparable from his living environment. Therefore, this article starts with creative environment of Li Bai's poetry

Fund Project: Shandong Social Science Planning Research Project "Research on the Chinese Poetry Music in Tang Dynasty and its Contemporary Value" (15CW YZ33); project of Li Bai Culture Research Center of Sichuan Philosophy and Social Science Key Research Base "Comparison of musical elements in Li Bai's poetry and modern poetry and exploration of its Contemporary Value" (LB16-01). and studies how the musical elements of Li Bai's poetry developed under the influence of different environments.

\section{THE CREATION ST AGE OF LI BAI'S POET RY WITH MUSICAL ELEMENTS}

Among Li Bai's poetry, music features of his Yuefu poems are obvious. Li Bai's Yuefu poems inherited the fine traditions of folk songs of the Han and Wei Dynasties, absorbed the essence of them, and enriched and developed his own musical poems. There are a lot of poems in Li Bai's Yuefu poem that can be sung with the music. Because the creation of Yuefu poems should be matched with the original music tunes, even some of the Yuefu poems cannot be sung with the music, these poems contain a lot of musical elements. Therefore, this article will take the time stage of the creation of Li Bai's Yuefu poems as a node to analyze the characteristics of the musical elements of Li Bai's poetry in different stages of creation.

The creation of Li Bai's Yuefu poems can be divided into 4 stages. First is the start-up period. During this period, Li Bai's Yuefu poems are themed with loyalty and lingering love, initially forming the unique poetic style of boldness and desolation. Second is the forming period. When his political ideal encounters setback, personal career is uncertain, he want to express depressed emotion and the creation surges out. Third is the expansion period. At this time the creative themes are various and the art style is mature. Fourth is the period of song-oriented trend. At this time, due to the influence of "Anshi Rebellion", themes and expressions of Li Bai's Yuefu poetry tend to be song-oriented.

\section{A. Start-up Period of Li Bai Yuefu Poetry (Before AD 730)}

In Li Bai's Yuefu poetry, two major themes of gallant spirit and love are reflected, which stems from his reading, roaming, chivalric knowledge and life experience. For example, "juvenile travel", "Swordmen's Legend", "White Horse articles" and other works reflect Li Bai's desire and pursuit of love. The poems of this period are basically classified as the Qing Shang poetry of Li Bai, of which the expressions are mild and form is natural. 


\section{B. The Forming Period of Li Bai's Yuefu Poem (AD 730 -} 742)

Li Bai came to Chang'an for the first time in order to realize the political ambition of "exerting his Wisdom to becoming Chancellor" at the year of thirty. He wanted to achieve the goal of becoming officer by creating excellent poetry. However, Li Bai was hit hard by the failure of politics. He realized the hardships of life and began to doubt the practice of the government. The masterpiece of this period such as "Bringing in the Wine", "Very difficult road", and "chant of Liang $\mathrm{Fu}$ " etc. express the depression, anguish and resentment in Li Bai's hearts. Most of the poems at this time are included in the "military odes" and "consistent poetry style" of Yuefu poems. Such poems have large band for accompaniment, with grand scale and momentum of singing and the number of singers is large with leading singer and chorus.

\section{The Expansion Period of Themes of Li Bai's Yuefu Poetry (AD 745-755)}

Li Bai came to Changan under the order from the government, to be recruited as Hanlin, but was given gold to return home in AD 744. After leaving Beijing, he met with $\mathrm{Du} \mathrm{Fu}$ in Luoyang and traveled Liangsong together. Since then, he began to roam in the north and south for 11 years until the outburst of "An-Shi Disturbances". During this period, Li Bai's Yuefu poems can be categorized as carols, remonstrances and sorrows according to the content such as "Spring Day", "Happiness above the cloud", "Hu Wuren", "Spring Song" and "War in South of City". Because in this period, Li Bai travel around and was influenced by local customs and music environment, and the poems adopt varied tunes. The styles of poetry singing are varied, which fully reflected the characteristics of local dialects. It also has some changes in tone pattern and rhyme.

\section{The Period of Song-oriented Trend of Li Bai's Yuefu Poetry (AD 755-762)}

"An-Shi Disturbances" broke out, so Li Bai closely linked his own destiny to the destiny of the country and the people unprecedentedly, hoping to make contributions to the relief of the common people. It reflected in the enhancement of topicality and narrativity, and Yuefu poetry has the songoriented tendency. For example, "fierce tiger" and "sad melody" etc. recount the suffering of the displaced people in "An Shi Disorder", express the poet's indignation to the rebels and his sympathy with the people and express his strong aspirations for mediation. At this stage, outstanding poets such as Li Bai and Bai Juyi set off the activity of reforming ancient Yuefu poems to create new themes and develop new Yuefu poems.

\section{TRACINGTHE MUSIC ENVIRONMENT OF Li BAi's POETRY}

\section{A. The Living Environment Leads Li Bai's Poetry to Have Musical Elements}

The colorful living environ ment has created the musical characteristics of Li Bai's poetry. Because Li Bai grew up in Sichuan Province, a place where ethnic minorities live together. There are beautiful mountains and rivers and the beauty of environment cannot be clearly described in words. The people there can both sing and dance well. They like music, so dancing people can be seen and pleasant voice of people can be heard everywhere in daily life. This growth environment created the generous character of being good at playing guqin and singing of Li Bai. As an adult, Li Bai traveled all over the country, with footprints cover Shaanxi, Hunan, Beijing, Xinjiang, Zhejiang, Jiangsu, Hebei, Anhui, Henan, Hubei, Shandong and Jiang xi and so on. Everywhere he arrived, Li Bai got in contact with local civilians to learn local folk songs and absorb nutrients from folk songs of all the places to write poetry, making it a precious wealth of classical music and culture. The living environment of Li Bai determines that $\mathrm{Li}$ Bai is a poet who likes music and is good at expressing music, which shows the profound background of Li Bai's poem and musical culture as well as the diversity of music.

\section{B. The International Exchange Environment Enhances the Performance of Musicality in Li Bai's Poetry}

Tang Dynasty was the heyday of the development of Chinese feudal society in politics, economy and culture. Brilliant achievements were obtained during the reign of nearly 300 years. In politics, they adopted the principle of "If China is in peace, all the minority nations will surrender." In terms of art, they adopted the principle of "taking in everything with all flowers blooming." Chang'an was an international metropolis in Li Bai period. The musical art of China was at the leading position in the world at that time. From Japan, Singapore, North Korea and Vietnam in Asia, to Rome in Western Europe, many music and arts talents in the world came to China for study and exchange. The music culture in Tang Dynasty is based on the traditional folk music and absorbs the musical culture style of the foreign nations, which enriches and perfects Chinese national art. It can be said that Tang Dynasty accomplished the biggest achievement in art culture in Chinese history. Rich music environment in Chang'an brings vitality to the musical development of Li Bai's poetry and has a profound impact on the music creation of Li Bai's poetry.

\section{The Political Emphasis on Music is Conducive to the Musical Development of Li Bai's Poetry}

The Tang Dynasty attaches great importance to music, since they think "musicians are the bodies of ancient sages.... sing the poems, ... pluck the string, and then it can clean the heart and make you think. Applying music to the country can make the government orderly, applying it to the world can make god relax, applying it to the party can bring harmony to emperor and minister and applying it to army can make 
soldiers brave." - Old Book of Tang: music. Based on this ideological foundation, the emperors of Tang Dynasty attached great importance to the role of music. First of all, music was widely used in the political affairs of Tang Dynasty, and different pieces of music and performances were used on different occasions and for different admin is trative needs. Second, because the emperors of Tang dynasty like chanting and singing poetry, many literati in the $\mathrm{Li}$ Bai era are given important position by the emperor and the government through their remonstrance of poetry and prose. Li Bai is the representative of such literati.

\section{The Cultural Environment Has Created the Musical Artistry of His Poetry}

According to the records in "Old Book of Tang: music", although Tang Dynasty followed the Sui system, and made innovation based on it. For example, removing Libi music and add Gao Chang music and Yan music, together ten music; among them, Qing Dynasty music is the native traditional music of the Central Plains, Yan music is a new kind of Chinese music, and the rest are foreign (exotic) music. According to the records of "New Book of Tang: Volume 22 rites and music", until the Kaiyuan Flourishing Age, "start Hu Department in the school," and propose "new sound cooperation between Dao tune, law song and $\mathrm{Hu}$ Department." In the grand ceremonies of the royal court, poetry singing became the means of rendering the atmosphere; at that time, in the royal court, feudal official and home of high officials and noble lords there are a large number of geisha and musicians, and chanting poetry became an elegant musical entertain ment and pastime form. At the gathering of literati and in the fields, there are traces of singing poetry. There has been the praise of "Taibai and Yuefu are the best". Geisha at that time takes singing Li Bai's poetry as a fashion.

\section{E. SWOT Analysis of the Overall Environment of Li Bai's Poetry Music}

SWOT is an analysis method of management, which is proposed by the management professor of University of San Francisco in the early 1980s. The four English SWOT letters represent: Strenth, Weakness, Opportunity, and Threat respectively and SWOT methods have now been applied to various fields. In studying the musicality of Li Bai's poetry, we use this method to fuse a variety of elements together, revealing Li Bai's excellent connotation of poetic culture and obvious poetic music features, and discovering a large number of music tracks therein as shown in "Table I".

TABLE I. SWOT ANALYSIS TABLE OF THE OVERALL ENVIRONMENT OFLI BAI'SPOETRY MUSIC CREATION

\begin{tabular}{|c|c|}
\hline S (Strength) & W (Weakness) \\
\hline 1. relatively stable political environment in peaceful and prosperous $\mathrm{T}$ ang & 1. mutual disguise of political bureaucratic in Tang Dynasty \\
\hline Dynasty & 2. relatively backward cultural transmission mode in Tang Dynasty \\
\hline 2. prosperity and strength of economy in Tang dynasty & 3. Li Bai's proud, narrow, and general character \\
\hline 3. Li Bai was born in Sichuan with rich music and poetry culture & 4. At the time, the political and cultural center of Tang Dynasty \\
\hline 4. At that time, the foundation of social culture was good & was limited to the western region \\
\hline 5. the spread of poetry and music by geisha in Tang Dynasty and its influence & 5. limitations of preference in Geisha spreading poetry and music \\
\hline 6. compet it iveness of large number of emerging literati & theme \\
\hline 7. mutual support and respected atmosphere of poetic creation formed by Li Bai & 6. brutal compet it ions of emerging literat $i$ \\
\hline 8. rich life experience of Li Bai's tour & \\
\hline O (Opportunity) & $\mathbf{T}(\mathbf{T}$ \\
\hline 1. election mechanism of literati becoming official & litical vi \\
\hline 2. Relative stable politics & 2. The danger of politicians fighting over their rights \\
\hline 3. The overall development $\mathrm{c}$ & 3. The life danger left in the war \\
\hline 4. The communicative space of "make friends by one's writing" in Tang Dynasty & 4. Notation method result in leaving only stylistic, but lost the \\
\hline 5. geisha in Tang Dynasty need new work for survival & origin of the music \\
\hline 6. int egrity of Poetry and music singing & 5. Limitations of the times limit the genre of poetry \\
\hline
\end{tabular}

Through the SWOT analysis of the overall environ ment of Li Bai's poetry music creation, we can understand that firstly in the process of Li Bai's pursuit of personal ideals, not being accepted politically, coupled with his personal arrogance, narrow sense of character, war and displaced experience and other disadvantages and threats give the poet the feeling of vicissitude; secondly, the cultural center of the Tang Dynasty is located in the western region and the geisha in Tang Dynasty affect the choice of the music themes when spreading poetry, which led to Li Bai's poems bold and unruly, reflecting the struggle and helplessness of $\mathrm{Li}$ Bai. However, with his own advantages and the opportunities of the society at that time, Li Bai was able to create more than a thousand poems in playing sword, singing songs and drinking wine. Among them, there were many topics of "happiness of singing, and sadness of sign", showing distinctive musical features.

\section{CONCLUSION}

In short, Li Bai as a saint in the poetry circles of Tang Dynasty, his musical features are obvious. Among the reasons why Li Bai's poems have distinctive musical features, the environmental factors play an important role. Growing in Sichuan where is the habitation of the people "good at singing and dancing with poetry" makes the seeds of music take root in Li Bai's young heart. Prosperity in economy and culture in Tang dynasty makes $\mathrm{Li}$ Bai feel the charm of foreign music. Emperors' love to poetry music in Tang Dynasty led Li Bai make efforts to create poetry and music.

\section{REFERENCES}

[1] Hou Yanshuang. Li Bai's poems and music. Chengdu: Sichuan People's Publishing House, 2009.9 (1). 
[2] Hou Yanshuang. On the music and singing of Li Bai's poems[J]. Chinese music, 2009,03:175.

[3] Hou Yanshuang. Music of Li Bai's poems[J]. Musical Work, 2009,04:106.

[4] Ren Bantang. Tang Sheng Shi volume one and volume two. Shanghai: Shanghai Chinese Classics Publishing House, 2006.

[5] Fu Xueyi. Chanting and Singing of Chinese Classical Poetry[J]. Music Research, 1994,03:37-43.

[6] Liu Chongde. Yuefu song poem[M]. Shijiangzhuang: Hebei university press, 2001.

[7] Ge Jingchun. Li Bai poetry and music in the Tang Dynasty [J]. literary heritage, 1995,03:49,50.

[8] Wu Xiangzhou. Research on the Relationship between poetry of the Tang Dynasty Greation and Singing Poems[M]. Beijing: Peking University Press, 2004.

[9] Guo Maoqian. Collection of Yuefu poetry[M]. Beijing: Zhonghua Book Company, 1979. 